Vol. 6(9), pp. 104-107, September 2014

DOI: $10.5897 /$ IJFA 14.0435

Article Number: 5C9C09548005

ISSN 2006-9839

Copyright (C2014

Author(s) retain the copyright of this article

http://www.academicjournals.org/ijfa

\title{
Parasites of some fishes (Labeo rohita and Schizothorax niger) of Jammu and Kashmir in India
}

\author{
Irfan-ur-Rauf Tak ${ }^{1}$, Shoaib Ali Dar ${ }^{1,2 *}$, M. Z. Chishti ${ }^{1}$, Harpreet Kaur ${ }^{2}$ and Gowhar Hamid Dar ${ }^{3}$ \\ ${ }^{1}$ Center of Research for Development, University of Kashmir, Srinagar, India. \\ ${ }^{2}$ Department of Zoology and Environmental Sciences, Punjabi University Patiala, India. \\ ${ }^{3}$ Department of Environmental Science, University of Kashmir, India.
}

Received 15 July, 2014; Accepted 10 September, 2014

\begin{abstract}
The present study has been carried out to find out the parasites of Schizothorax niger and Labeo rohita during different months of the year 2013 to 2014. Parasites belonging to two groups viz. ciliophoran (Chilodonella) and crustacean (Argulus) were recorded from 200 fishes of Rohu (L. rohita) and S. niger collected from different parts of Jammu and Kashmir. These two parasites belong to Ectoparasitic group and no other parasite was recorded in the present study. The highest prevalence $(60 \%)$ of infection has been recorded in ciliophorans and the lowest was in crustacean (48\%). It was observed that highest parasitic prevalence $(54 \%)$ was recorded during winter season (December-February) while the lowest prevalence (0\%) recorded during rainy season (June-August). Cyprinid fish S. niger infested with ciliophoran had no pathogenic signs and the clinical signs were represented as increase of mucus laden masses on the surface of gills. No pathogenic signs were seen in L. rohita infested with Crustacean parasite and clinical signs were represented as gasping air, pale skin color, sluggish swimming, increase of mucus production and floating on surface often causes mortality. This is first report of protozoan parasites from fishes of Jammu and Kashmir.
\end{abstract}

Key words: Ectoparasites, Protozoan, Ciliophoran, Labeo rohita, Schizothorax niger.

\section{INTRODUCTION}

Jammu and Kashmir bestowed with water resources of about 40,000 ha comprising lakes, streams, rivers, sars, springs etc. suitable for fish culture. Aquaculture is one of the most economically important applied strategies all over the world and fishes are one of the most beneficial and nutritional resources of human beings. The entire water area of Jammu and Kashmir supports the potential fish farming of the state as well as the whole country. The major carp farming mainly dominates in Jammu. The most important prerequisite of fish production is availability of healthy fish fingerlings of carps. It is evident from the available literature that the parasitic diseases have caused significant damage in nursery system of carp fishes mostly affecting the fry and fingerlings (Gopalkrisnan, 1961). The parasitic community of fish show considerable changes with the environmental conditions in which fish live (Hossain et al., 2008).

Fish harbor a variety of parasites viz., protozoa,

*Corresponding author. E-mail: darshoaib786@gmail.com.

Author(s) agree that this article remain permanently open access under the terms of the Creative Commons Attribution License 4.0 International License 
cestodes, trematodes and acanthocephalans (Ali, 1990) and the degree of damage by infection is influenced to a large extent by the type and numbers of parasites present (Bauer, 1941). When they are present in large numbers, can often cause gross pathological changes and damages to the host (Heckman, 1996; Hoffman, 1998). Some of the environmental conditions are more conducive to disease among which water temperature is one of the important criteria associated with disease outbreak. According to Mitra and Haldar (2004) in their First Record of Chilodonella hexasticha in West Bengal India parasites occur mainly in the colder months and in summer no infection was recorded.

Workers have observed that the prevalence of the disease was more in the winter season (Ahmed et al., 1991) than the other months of the year. A significant work has been done on Ciliophorans in the Indian freshwater and estuarine fishes by Mitra et al. (2013), Mitra and Bandyopadhyay (2005, 2006a, b, 2009), Mitra et al. (2012a, b) and Ortega and Aguilar (2014) while working on parasites of fishes in mexico recorded first report of ciliates belonging to genus Trichodina parasitizing characid fish Astyanax mexicanusin as previous reports were from exotic cultured fishes (AladroLubel et al., 2006). Asian carps being the original host and has been introduced to different countries including Mexico. Keeping in view the increasing importance of fish as a cheap source of protein rich diet, protozoan infections in fresh water fishes has drawn attention of the fish biologists and parasitologists worldwide. Labeo rohita is much demanded and highly cultured fish in farms of Jammu Division and S. niger local fish of Kashmir also highly demanded food fish in Kashmir Division. To our knowledge no study has been done on these protozoan parasites in fishes of Jammu and Kashmir that is why the present study deals with parasitic prevalence of $L$. rohita and $S$. niger from Jammu and Kashmir which are commercially important food fishes of Jammu and Kashmir.

\section{MATERIALS AND METHODS}

The present study was done during the period of July 2013 to June 2014. Live carp fishes having an average weight of $300 \mathrm{~g}$ belonging to two species, that is, Rohu ( $L$. rohita), were randomly collected from the adjacent fish market and ponds of Jammu and local Snowtrout $S$. niger collected through local fishermen from River Jhelum and Dal Lake in Kashmir. 200 fishes were observed for all types of parasitic infection. The fishes were collected and brought to Parasitology Laboratory Center of Research for Development (CORD), University of Kashmir for further examination. All the body organs were examined for parasitic infection. The smear of different organs were prepared on clean grease free slides with a drop of $0.5 \% \mathrm{NaCl}$ solution and air-dried. The clinical and pathogenic signs were investigated. The ciliophoran parasites were subjected to silver nitrate impregnation after the method of Klein (1958) and crustacean parasites were stained with lactophenol cotton blue stain for permanent preparation. The four seasons were designed as June to August (Rainy), September to November (Autumn),
December to February (Winter) and March to May (Summer). The prevalence was calculated as the percentage (\%) of infested fish over the total number of analysed fish.

\section{RESULTS AND DISCUSSION}

Naturally infested Cyprinid fish $S$. niger had no pathogenic signs and the clinical signs were represented as mucus laden masses present on the surface of gills. No pathogenic signs were seen in $L$. rohita and clinical signs were represented as gasping air, pale skin color, sluggish swimming and increase in mucus production. Fishes were seen floating on surface and most oftenly mortality was seen in the floating fishes. Crustacean parasites, that is, Argulus spp. were recorded in fish ponds around Jammu and infected fish was $L$. rohita and Ciliophorans, that is, Chilodonella spp. were recorded in River Jehlum and Dal lake and infected fish was $S$. niger. Abundance of Ciliophorans were mostly found on fishes of River Jhelum. The percentage of infection by different ectoparasites in four groups with months has been incorporated in Table 1. Out of 200 fishes 40 were infected with ciliophorans which means average of 20 and similarly is the case of crustaceans an average of 13 was found. The average prevalence of each group of ectoparasites, that is, ciliophoran and crustacean together have been listed in Table 2 showing prevalence of both the groups in the same season. It is clear from the table that prevalence of ectoparasitic infection changes with month. In winter season, that is, December to February it reaches its peak as is shown in Table 2. Crustacean parasites are found only in the months of December to May but not in rest of the year similarly CHILODONELLA infection is absent in the month of June to August.

The results reveal that the ectoparasitic infection is heavy during the months of Winter, that is, December to February similarly (Bhuiyan et al., 2007; Ahmed et al., 1991) have reported their occurance during Winter in their study. Many other workers such as Akhter et al. (1997), Banu et al. (1993), Chandra et al. (1997) and Hossain et al. (1994) have also found similar observations and heavy infections in the particular season of the Year. Some authors have recorded that ectoparasites have maximum rate of infection both in winter and spring (Abu El-Wafa, 1988; Hassan, 1999; Özer and Erdem, 1999; Özer, 2000, 2003; Jerônimo et al., 2011). Also it has been found that low temperatures being more congineal for reproduction of Chilodonella spp. The more parasitic infection in rainy season indicates that the ectoparasitic infection changed with the change of season. Similarly it was observed by Mortuza and Al-Misned (2013) in their study regarding the different parasitic infections in fishes. Researchers such as (Rahman et al., 2007; Farhaduzzaman et al., 2010; Mofasshalin et al., 2012) have reported that Winter as a period of high susceptibility of fish to pathogens 
Table 1. Prevalence of parasites in L. rohita and S. niger in different seasons of the year.

\begin{tabular}{|c|c|c|c|c|c|c|}
\hline Month & Ciliophorans & $\begin{array}{c}\text { Prevalence } \\
(\%)\end{array}$ & $\begin{array}{c}\text { Site of } \\
\text { infection }\end{array}$ & Crustaceans & $\begin{array}{c}\text { Prevalence } \\
(\%)\end{array}$ & Site of infection \\
\hline June - August & Chilodonella spp. & 0 & Gills & Argulus spp. & 0 & Skin and Fins \\
\hline September - November & Chilodonella spp. & 12 & Gills & Argulus spp. & 0 & Skin and Fins \\
\hline December - February & Chilodonella spp. & 60 & Gills & Argulus spp. & 48 & Skin and Fins \\
\hline March - May & Chilodonella spp. & 8 & Gills & Argulus spp. & 4 & Skin and Fins \\
\hline Average in total Year & Ciliophorans & \multicolumn{2}{|c|}{20} & Crustacean & \multicolumn{2}{|c|}{13} \\
\hline
\end{tabular}

Table 2. Monthly prevalence (\%) of parasites in L. rohita and S. niger.

\begin{tabular}{lcccc}
\hline Parasite & June - August & September - November & December - February & March - May \\
\hline Ciliophorans & 0 & 6 & 30 & 4 \\
Crustaceans & 0 & 0 & 24 & 2 \\
Average of total parasitic prevalence & 0 & 6 & 54 & 6 \\
\hline
\end{tabular}

especially Ectoparasites.

Due to high stocking density of fingerlings and Polyculture practices employed is another reason for ectoparasitic disease outbreak (Hossain et al., 2008). This may also increase the chance of ectoparasite transmission from fish to fish easily and the availability of host for the disease transmission. Gills of $S$. niger were found infected with Chilodonella spp. and fins, skin of $L$. rohita were found infected with Argulus spp. Similarly (Bhuiyan et al., 2007) have recorded similar observations in their study which may also indicate their tissue specificity.

\section{Conclusion}

Thus it can be concluded that biological factors of host and the water quality has a great impact on the abundance of parasites and their ability to survive on the host. Proper stocking density is important to reduce disease outbreak and water quality should be maintained properly to avoid parasitic infection in pond. Gills, fins and skin were mostly found infected. The medium size fishes having a size of 100 to $150 \mathrm{~g}$ were found to be more vulnerable due to their poor immunity power and wide spread surface area, which may favours more colonization of parasites.

\section{REFERENCES}

Abu El-Wafa SAD (1988). Protozoa parasites of some freshwater fishes in Behera Governorate. M.V.Sc. Thesis, Alexandria University.

Ahmed A, Ali SMK, Samad A (1991). Probable cause of fish ulcer in Bangladesh. Nutr. News. 14(1):3.

Akhter M, DSilva J, Khatun A (1997). Helminth Parasites of Anabas testudineus (Bloch.) in Bangladesh. Bangl. J. Zool, 25:135-138.

Aladro-Lubel MA, Mayen-Estrada R, Reyes Santos M (2006). Listados
Faunisticos de Mexico XI. Registro actualizado de ciliados (agosto, 2004). Instituto de Biologia, UNAM, D. F. 97 p.

Ali SS (1990). An Introduction to Fresh Water Fishery Biology. University Grants Commission, Islamabad, Pakistan. pp. 142-145.

Banu ANH, Hossain MA, Khan MH (1993). Investigation into the occurrence of parasites in carps, catfish and tilapia. Progr. Agric. 4:11-16.

Bauer ON (1941). Contributions to the knowledge of fish parasites of the river Khatanga. Tr. Inta. Pol. Zeml. ser. Prom. Khaz, 16:84-103.

Bhuiyan AS, Akther S, Musa GM (2007). Occurrence of parasites in Labeo rohita (Hamilton) from Rajshahi. Univ. J. Zool. 26:31-34.

Chandra KJ, Islam KZ, Wootten R (1997). Some aspects of association and development of Lytocestus indicus moghe in catfish, Clarias batrachus in Bangladesh. J. Fish. Res. 1:31-38.

Farhaduzzaman AM, Alam MM, Hossain M, Hussain MA, Rahman MH (2010). Prevalence of parasites in the Indian major carp, Labeo rohita (Hamilton) in Rajshahi, Bangladesh. Univ. J. Zool. Rajshahi. Univ, 28:65-68. http://dx.doi.org/10.3329/ujzru.v28i0.5290

Gopalkrisnan V (1961). Observation on a new epidemical eye disease affecting the Indian Carp Catla catla (Hamilton-Buchanan). Ind. J. Fish 8:222-232.

Hassan MAH (1999). Trichodiniasis in farmed freshwater Tilapiain Eastern Saudi Arabia. J. King Abdulaziz Univer. Mar. Sci. 10:157168. http://dx.doi.org/10.4197/mar.10-1.11

Heckman R (1996). Protozoan parasites of fish, part 1. Aquat. Mag, 22(3):44-57.

Hoffman GL (1998). Parasites of North American freshwater fishes. Second edition. Univ. California Press, London.

Hossain MA, Banu ANH, Khan MH (1994). Prevalence of ectoparasite in carp nursery operation of greater Mymen singh. Progr. Agric. 5:3944.

Hossain MD, Hossain MK, Rahaman MH, Akter A, Khanom DA (2008). Prevalence of ectoparasites of carp fingerlings at Santaher, Bogra. Univ. J. Zool. Rajshahi. Univ. 27:17-19.

Jerônimo GT, Speck GM, Cechinel MM, Gonçalves ELT, Martins ML (2011). Seasonal variation on the ectoparasitic communities of Nile tilapia cultured in three regions in southern Brazilian. Braz. J. Biol, 71:365-373. http://dx.doi.org/10.1590/S1519-69842011000300005

Klein BM (1958). The dry silver method and its proper use. J. Protozool, 5:99-103. http://dx.doi.org/10.1111/j.1550-7408.1958.tb02535.x Mitra AK, Bandyopadhyay PK (2005) First records of Trichodina japonica Imai, Miyazaki et Nomura 1991 and Trichodina mutabilis Kazubski et Migala 1968 (Ciliophora, Trichodinidae) from Indian fishes. Protistol. 4(2):121-127.

Mitra AK, Bandyopadhyay PK (2006a). First records of ectoparasitic 
African Trichodinids (Ciliophora: Peritrichida) in a Cichlid fish Oreochromis mossambicus (Peters 1852) from the Churni River System, West Bengal, India. Animal. Biol. 56(3):323-333.

Mitra AK, Bandyopadhyay PK (2006b). Trichodina haldari n.sp. and Paratrichodina bassonae n.sp. (Ciliophora: Peritrichida) from Indian freshwater fishes. Acta. Protozool. 45:289-294.

Mitra AK, Bandyopadhyay PK (2009). Dipartiella kazubski sp. nov. (Ciliophora: Peritrichida), a new ectoparasitic trichodinid species from the gills of freshwater fishes in India. Protistol. 6(1):33-38.

Mitra AK, Bandyopadhyay PK, Gong Y (2013). Studies on Trichodinid and Chilodonellid Ciliophorans (Protozoa: Ciliophora) in the Indian freshwater and estuarine fishes with description of Trichodinella sunderbanensis sp. nov. andTrichodina nandusi sp. nov. Parasitol. Res. 112:1077-1085. http://dx.doi.org/10.1007/s00436-012-3234-x

Mitra AK, Bandyopadhyay PK, Gong Y, Goswami M, Bhowmik B (2012b). Description of two new species of ectoparasitic Trichodina Ehrenberg, 1830 (Ciliophora: Trichodinidae) from freshwater fishes in the river Ganges, India. J. Parasit. Dis. doi:10.1007/ s12639-0120126-z.

Mitra AK, Haldar D (2004). First Record of Chilodonella hexasticha (Kiernik, 1909) Kahl, 1931 (Ciliophora: Chilodonellidae) infesting a freshwater fish Nandus nandus (Hamilton) from Gangetic West Bengal, India. Anim. Biol. 54:111-118. http://dx.doi.org/10.1163/1570756041445182

Mitra AK, Bandyopadhyay PK, Gong Y, Bhowmik B (2012a). Occurrence of Trichodinid Ciliophorans (Ciliophora: Peritrichida) in the fresh-water fishes of river Churni with description of Trichodina glossogobae sp. nov. in West Bengal, India. J. Parasit. Dis. 36(1):3443. http://dx.doi.org/10.1007/s12639-011-0073-0.

Mofasshalin MS, Bashar MA, Alam MM, Alam GM, Moumita D, Mazlan AG, Simon KD (2012). Parasites of three Indian minor carps of Rajshahi, Bangladesh. Asian. J. Anim. Vet. Adv. 7(7):613-620. http://dx.doi.org/10.3923/ajava.2012.613.620
Mortuza GM, Al Misned FA (2013). Prevalence of ectoparasites in carp fry and fingerlings of Rajshahi district, Bangladesh. J. Parasit. Dis, DOI 10.1007/s12639-013-0296-3. http://dx.doi.org/10.1007/s12639013-0296-3

Ortega AGI, Aguilar RA (2014). Trichodina mutabilis (Protozoa: Ciliophora: Trichodinidae) from the characid fish Astyanax mexicanus in the Cuatro Ciénegas region, northern Mexico. Rev. Mex. Biodivers. 85:613-616.

Özer A (2000). The occurrence of three species of Trichodina (Ciliophora: Peritrichia) on Cyprinus carpio in relation to culture conditions, seasonality and host characteristics. Acta. Protozool, 39:61-66.

Özer A (2003). Trichodina domerguei Wallengren, 1987 (Ciliophora: Peritrichia) infestations on the Round Goby, Neogobius melanostomus Pallas, 1811 in relation to seasonality and host factors. Comp. Parasitol, 70: 132-135.http://dx.doi.org/10.1654/4073

Özer A, Erdem O (1999). The relationship between occurrence of ectoparasites, temperature and culture conditions; A comparison of farmed and wild common carp (Cyprinus carpio L., 1758) in the Sinop region of northern Turkey. J. Nat. Hist. 33:483-491. http://dx.doi.org/10.1080/002229399300209

Rahman MR, Akter MA, Hossain MD (2007). Parasitic diseases of exotic carp in Bangladesh. J. Agric. Rural. Dev. 5(1\&2):127-134. 